0.0. Ломейко

Запорізький державний медичний університет

\title{
Особливості ендокринного статусу та кількісні порушення спермограми у чоловіків, які працюють в умовах високих та низьких температур
}

Мета - вивчити особливості морфології сперматозоїдів та показники ендокринного статусу в чоловіків, які працюють в умовах високих та низьких температур. Об'єкт і методи дослідження. У період 2013-2017 рр. обстежено спермограми 81 пацієнта, які впродовж професійної діяльності перебували під впливом низьких ( $n=43$ ) або високих $(n=38)$ температур. Результати. Встановлено, що гормональний статус чоловіків, які працюють в умовах високих температур, характеризується вірогідним підвищенням вмісту лютеїнізуючого гормону (p=0,013). У групі чоловіків, які працюють в умовах низьких температур, зміни гормонального статусу невірогідні. Доведено наявність від'ємного кореляційного зв'язку між загальною кількістю сперматозоїдів в еякуляті з тривалістю професійного анамнезу при роботі в умовах високих $(r=-0,67 ; p<0,05)$ та низьких $(r=-0,36 ; p<0,05)$ температур. Висновки. В умовах впливу високих та низьких температур кількість сперматозоїдів (як загальна, так і в 1 мл еякуляту) вірогідно менша (p<0,05), ніж у групі контролю. Кількість рухливих сперматозоїдів найбільш «вразлива» при впливі низьких температур $(p<0,05)$. Для високих температур «вразливими» параметрами $\epsilon$ зменшення загальної кількості в 1 мл еякуляту <15,0\% (78,9\%), кількості живих сперматозоїдів <58,0\% (65,8\%), кількості сперматозоїдів з поступальним рухом <32,0\% (60,5\%).

Ключові слова: ендокринний статус, сперматозоїди, морфологічні зміни, низькі температури, високі температури.

\section{Вступ}

Сьогодні у світі налічують 60-80 млн безплідних пар: 40\% випадків спричинено чоловічим безпліддям, 40\% - жіночим, решта 20,0\% - обох партнерів (Meniru G.I., 2004; Тимченко O.I. та співавт., 2014). За даними Всесвітньої організації охорони здоров'я (ВООЗ), безпліддя часто сприймають як переважно жіноче захворювання, попри те, що чоловіче безпліддя поширене тією самою мірою (Shcheplev P.A., Apolikhin O.I. 2010; Arya S.T., Dibb B., 2016).

Зовнішні умови мають вагомий внесок у розвитку захворювань репродуктивної сфери учоловіків, хоча їх причина і структура досі встановлені нечітко і $є$ суперечливими, незважаючи на переконливу низку чинників, що порушують сперматогенез (Ozelci R. et al., 2016; Punab M. et al., 2016).

Дослідження чоловічої інфертильності в умовах великого промислового міста, впливу високих та низьких температур на тестикулярну тканину, показників спермограми та ендокринного статусу -актуальні питання андрології та репродуктології. Так, одним з екстремальних факторів середовища, які впливають на фертильність чоловіків, $€$ високі та низькі температури в умовах промислового виробництва. Однак у доступній літературі є лише поодинокі роботи, в яких вивчали вплив низьких температур на репродуктивну систему.

Мета - вивчити особливості морфології сперматозоїдів тапоказників ендокринного статусу у чоловіків, які працюють в умовах високих та низьких температур.

\section{Об'єкт і методи дослідження}

У період 2013-2017 рр. обстежено спермограми пацієнтів $(n=81)$, які впродовж професійної діяльності перебували під впливом низьких $(n=43)$ або високих $(n=38)$ температур. Обстеження проводили на базі кафедри акушерства та гінекології Запорізького державного університету та Комунальної установи «Обласний медичний центр репродукції людини» (Запоріжжя).

Критеріями включення до основної групи були репродуктивний вік пацієнтів, анамнез інфертильності >1 року, робота в умовах високих або низьких температур, відсутність гострих запальних процесів в урогенітальному тракті та відсутність гормональної корекції безпліддя до моменту включення в дослідження.

Групу порівняння становили 25 практично здорових осіб віком 25-42 роки (середній вік - 32,9 5,36 року, що вірогідно не відрізнялося від основної групи), в яких, за даними анамнезу, професійна діяльність не була пов'язана із впливом несприятливих факторів.

Фізикальне обстеження включало оцінку загального соматичного статусу та стану органів сечостатевої системи пацієнта.

Верифікацію діагнозу та причин безпліддя проводили з використанням критеріїв МОЗ України (2003).

Гормональні дослідження (тиреотропний гормон, фолікулостимулюючий гормон (ФСГ), лютеїнізуючий гормон (ЛГ), пролактин, прогестерон, естрадіол, тестостерон) проводили на імуноферментному аналізаторі «Rayto 2000» із використанням діагностичних наборів фірми «Siemens».

Розрахунок рівня вільного тестостерону (ВТ) проводили на підставі концентрацій загального тестостерону (ЗТ) і глобуліну, що зв'язує статеві гормони, з використанням номограми Вермюлена. Вивчення основних параметрів еякуляту та сперміологічний аналіз проводили відповідно до вимог ВООЗ 5-го видання 2010 р.

Для характеристики інформативності кількісних та якісних показників спермограми з метою оцінки впливу високих та низьких температур використовували об'єктивні параметри, визначені як операційні характеристики тестів. До найважливіших операційних характеристик методів діагностики відносили чутливість і специфічність.

Статистичний аналіз отриманих результатів проводили з використанням пакета програм «Statistica for Windows» версії 7.0 («StatSoft Inc.», США). Для оцінки залежності між перемінними використовували кореляційний аналіз за Пірсоном. Кількісні показники представлені у вигляді середнє \pm стандартне відхилення (Rebrova O.Yu., 2004).

\section{Результати та їх обговорення}

Гормональний статус чоловіків, які працюють в умовах високих температур, вірогідно не відрізнявся від контрольної групи, окрім вмісту ЛГ (на 46,5\%; $p=0,013$ ). Для інших показників відзначено тенденцію до зниження ЗТ та ВТ (на 17,9 та 7,6\% відповідно), про- 
лактину (на 10,8\%), підвищення вмісту ФСГ (на 9,7\%) та кортизолу (на $11,2 \%)$. Подібну закономірність виявлено у групі чоловіків, які працюють в умовах низьких температур: тенденції до підвищення вмісту ЛГ $(14,6 \%)$ та ФСГ $(4,4 \%)$, а також кортизолу (на 5,6\%), зниження рівня ЗТ (на 9,9\%) та ВТ (на 17,6\%) (табл. 1).

Таблиця 1. Гормональний статус чоловіків, які працюють в умовах високих та низьких температур

\begin{tabular}{|c|c|c|c|}
\hline \multirow{2}{*}{ Показник } & \multirow{2}{*}{$\begin{array}{c}\text { Контроль } \\
(n=25)\end{array}$} & \multicolumn{2}{|c|}{ Температури } \\
\hline & & високі $(n=38)$ & низькі $(n=43)$ \\
\hline ЗТ, нмоль/л & $24,4 \pm 9,82$ & $20,7 \pm 9,12$ & $22,2 \pm 10,1$ \\
\hline ВТ, нмоль/л & $12,7 \pm 3,86$ & $11,8 \pm 6,11$ & $10,8 \pm 5,12$ \\
\hline ЛГ, мЕд/мЛ & $3,42 \pm 1,18$ & $5,01 \pm 2,15^{\star}$ & $3,92 \pm 1,72$ \\
\hline ФСГ, мЕд/мЛ & $4,7 \pm 1,95$ & $5,16 \pm 1,97$ & $4,91 \pm 2,07$ \\
\hline Пролактин, мЕд/мл & $235,8 \pm 128,9$ & $212,8 \pm 112,8$ & $235,4 \pm 132,4$ \\
\hline Кортизол, нмоль/л & $212,5 \pm 98,8$ & $236,3 \pm 102,8$ & $224,5 \pm 112,5$ \\
\hline Інсулін, мкОД/мл & $21,51 \pm 11,2$ & $22,71 \pm 10,9$ & $20,8 \pm 8,96$ \\
\hline
\end{tabular}

*Вірогідна різниця відносно групи контролю.

Результати верифікації загальної кількості рухливих сперматозоїдів та кількості рухливих сперматозоїдів із поступальним рухом у чоловіків, які працюють в умовах високих та низьких температур, наведено в табл. 2. Встановлено вірогідне зменшення кількості рухливих сперматозоїдів $(p<0,05)$, проте найбільш «вразливим» цей показник був при впливі низьких температур, що вірогідно відрізнялося як від контрольної групи, так і від групи чоловіків, шкідливим чинником в яких була робота в умовах високих температур $\left(p, p_{1}<0,05\right)$.

Таблиця 2. Кількість рухливих сперматозоїдів у чоловіків, які працюють в умовах високих та низьких температур

\begin{tabular}{cccc}
\hline \multirow{2}{*}{$\begin{array}{c}\text { Кількість рухливих } \\
\text { сперматозоїдів }\end{array}$} & \multirow{2}{*}{ Контроль } & \multicolumn{2}{c}{ Температури } \\
\cline { 3 - 4 } & & високі & низькі \\
& $\mathbf{( n = 3 8 )}$ & $(\mathbf{n}=\mathbf{4 3})$ \\
\hline 3 поступальним та непоступальним рухом & $44,8 \pm 9,81$ & $37,7 \pm 8,19$ & $30,9 \pm 7,81$ \\
& & $p<0,05$ & $p, p_{1}<0,05$ \\
3 поступальним рухом & $37,9 \pm 6,89$ & $30,5 \pm 7,82$ & $26,6 \pm 5,67$ \\
& & $p<0,05$ & $p, p_{1}<0,05$ \\
\hline
\end{tabular}

Вірогідність різниці показників: $p$ - між контрольною та дослідними групами; $p_{1}$ - між групами чоловіків, які працюють в умовах високих та низьких температур.

Середня тривалість професійного анамнезу при роботі в умо-

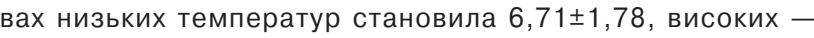
$7,21 \pm 1,54$ років. Встановлено наявність вірогідного від'ємного кореляційного зв'язку $(r=-0,67 ; p<0,05)$ між загальною кількістю сперматозоїдів в еякуляті та тривалістю професійного анамнезу у чоловіків, які працюють в умовах високих (рис. 1) та низьких (рис. 2) температур ( $r=-0,36 ; p<0,05)$.

Проведено кількісну оцінку основних параметрів еякуляту відповідно до вимог ВООЗ 5-го видання 2010 р. Абсолютне (n) та відносне (\%) співвідношення кількісних параметрів спермограми в умовах високих та низьких температур наведено в табл. 3.

Таблиця 3. Порушення кількісних показників спермограми при роботі в умовах високих та низьких температур

\section{Кількісні показники спермограми}

Зменшення загальної кількості в 1 мл еякуляту $<15,0 \%$ Зменшення кількості живих сперматозоїдів $<58,0 \%$ Зменшення кількості рухливих сперматозоїдів в еякуляті $<40,0 \%$

Зменшення кількості сперматозоїдів із поступальним $23 \quad 60,5 \quad 34 \quad 79,1$ рухом $<32,0 \%$

Для високих температур більш «вразливими» параметрами були зменшення загальної кількостів 1 мл еякуляту <15,0\% (78,9\%), кількості живих сперматозоїдів <58,0\% (65,8\%) та кількості сперматозоїдів із поступальним рухом $<32,0 \%(60,5 \%)$, для низьких температур - зменшення кількості рухливих сперматозоїдів в еякуляті $<40,0 \%(67,4 \%)$ та кількості сперматозоїдів з поступальним рухом $<32,0 \%(79,1 \%)$ (див. табл. 3).

Аналіз структури розподілу пацієнтів залежно від загальної кількості сперматозоїдів, живих сперматозоїдів та рухливих сперматозоїдів при дії високих і низьких температур показав, що у більшості пацієнтів цей показник був менше нижньої межі норми згідно з рекомендаціями ВООЗ, що відповідає критеріям олігозооспермії та астенозооспермії (табл. 4).

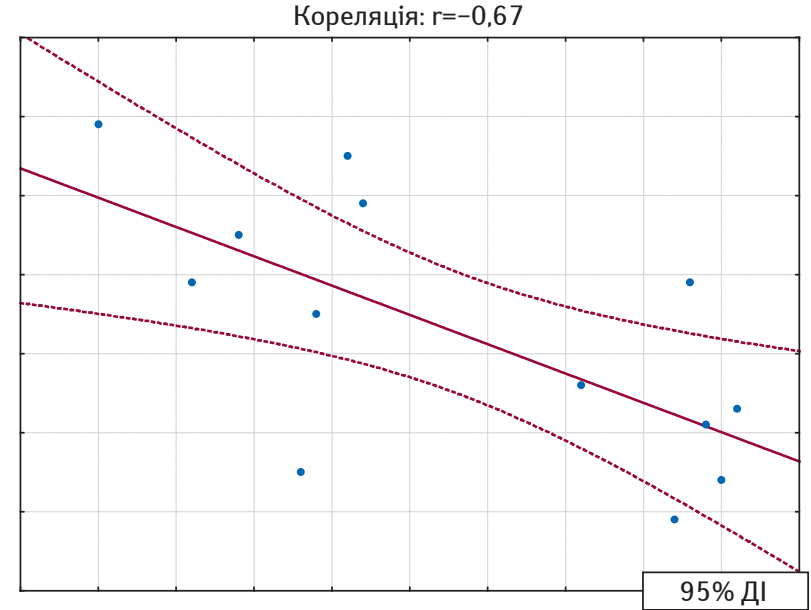

Рис. 1. Зв'язок між загальною кількістю сперматозоїдів в еякуляті та тривалістю професійного анамнезу в умовах високих температур

Кореляція: $r=-0,36$

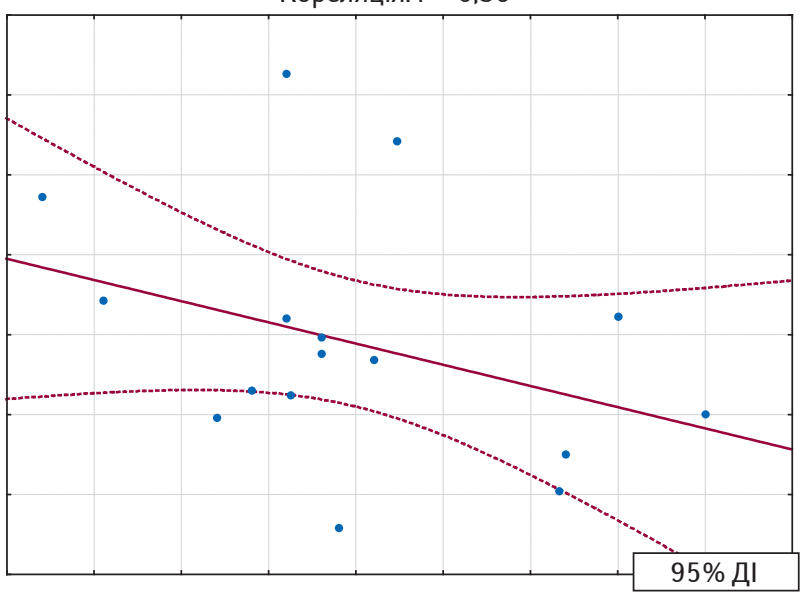

Рис. 2. Зв'язок між кількістю рухливих сперматозоїдів і тривалістю професійного анамнезу в умовах низьких температур

Таблиця 4. Порушення якісних показників спермограми чоловіків при роботі в умовах високих та низьких температур

\section{Якісні показники спермограми}

\begin{tabular}{cccc}
\multicolumn{3}{c}{ Температури } \\
\hline \multicolumn{2}{c}{ високі } & \multicolumn{2}{c}{ низькі } \\
(n=38) & \multicolumn{2}{c}{ (n=43) } \\
\hline n & $\%$ & n & $\%$ \\
\hline 4 & 10,5 & 21 & 48,8
\end{tabular}

Кількість нормальних за морфологією сперматозоїдів (строгий критерій Крюгера)

Наявність аномальних сперматозоїдів (патозооспермія) $31 \quad 81,6 \quad 24 \quad 55,8$

Наявність фрагментації ДНК

Наявність патології голівок сперматозоїдів

Наявність патології акросоми сперматозоїдів

$\begin{array}{llll}30 & 78,9 & 17 & 39,5\end{array}$

$26 \quad 68,4 \quad 15 \quad 34,9$

Наявність патології джгутика

$\begin{array}{llll}16 & 42,1 & 19 & 44,1\end{array}$

$24 \quad 63,2 \quad 27 \quad 62,8$

Наявність патологічно змінених сперматозоїдів при дії високих температур (табл. 5) була чутливою (89,4; 95\% довірчий інтервал (ДІ) 75,9-95,8) та високоспецифічною ознакою $(96,0 ; 95 \%$ ДІ 80,5-99,3) з площею під ROC-кривою 92,7 (95\% ДІ 86,5-98,9), на відміну від чоловіків, якіпрацювали в умовахнизькихтемператур (табл. 6), в яких показник був з меншою чутливістю (51,2; 95\% ДІ 36,8-65,4).

Відзначено вищу частоту виявлення патозооспермії при дії високихтемператур (див. табл. 5) із чутливістю 81,6 (95\% ДІ 66,5-90,8), специфічністю 96,0 (95\% ДІ 80,5-99,3), вірогідними «шансами» виявлення цієї ознаки 106,3 (95\% ДІ 12,2-923,5) та площею під ROCкривою 88,8 (95\% ДІ 81,5-96,1).

При дії низьких температур діагностична цінність виявлення патозооспермії була нижчою, проте також вірогідною за показниками чутливості (55,8; 95\% ДІ 41,1-69,6), специфічності (96,0; 95\% ДІ 80,5-99,3) та площі під ROC-кривою (75,9; 95\% ДІ 67,6-84,3) (табл. 6).

Діагностична цінність наявності фрагментації ДНК сперматозоїдів в умовах високих температур встановлена на рівні ві- 
рогідної чутливості 78,9 (95\% ДІ 63,6-88,9), специфічності 96,0 (95\% ДІ 80,5-99,3). «Шанси» виявлення цієї ознаки були також високими та вірогідними: ВШ 90,0 (95\% ДІ 10,5-770,3), площа під ROC-кривою 87,5 (95\% ДІ 79,9-95,0) (див. табл. 5). Значно нижчою була діагностична чутливість і специфічність виявлення фрагментації ДНК сперматозоїдів в умовах низьких температур: чутливість 39,5 (95\% ДІ 26,4-54,4), ВШ 15,7 (95\% ДІ 1,9-127,1) (див. табл. 6).

Таблиця 5. Діагностична цінність морфологічних ознак спермограми чоловіків при роботі в умовах високих температур

\begin{tabular}{|c|c|c|c|c|}
\hline Показник & $\begin{array}{c}\text { Чутливість } \\
\text { (95\% ДІ) }\end{array}$ & $\begin{array}{c}\text { Специфіч- } \\
\text { ність } \\
\text { (95\% ДІ) }\end{array}$ & $\begin{array}{c}\text { Відношення } \\
\text { шансів (ВШ) } \\
\text { (95\% ДІ) }\end{array}$ & $\begin{array}{c}\text { Площа під } \\
\text { воС- } \\
\text { кривою } \\
\text { (95\% ДІ) }\end{array}$ \\
\hline Кількість нормальних & 89,4 & 96,0 & 204,0 & 92,7 \\
\hline $\begin{array}{l}\text { за мо } \\
\text { сперк }\end{array}$ & & & & \\
\hline мальних & & 96,0 & & \\
\hline сперм & $(66,5$ & $(80,5-$ & $(12,2-923,5)$ & $(81,5$ \\
\hline Наявність фрагментації ДНК & $\begin{array}{c}78,9 \\
(63,6-88,9)\end{array}$ & $\begin{array}{c}96,0 \\
(80,5-99,3)\end{array}$ & $\begin{array}{c}90,0 \\
(10,5-770,3)\end{array}$ & $\begin{array}{r}8 \\
(79,9\end{array}$ \\
\hline Наявність & 68,4 & 92,0 & 24,9 & \\
\hline сперматоз & $(52,5-80,9)$ & $(75,0-97,7)$ & $(5,0-1$ & $(71,1$ \\
\hline Наявність патології & & 96,0 & 17,5 & \\
\hline акросоми сперматозоїдів & $(27,8-57,8)$ & $(80,5-99,3)$ & $(2,1-142,7)$ & $(60,3-77,8$ \\
\hline Наявність патології & 63,1 & 96,0 & 41,1 & 79,6 \\
\hline джгутика & $(47,3-76,6)$ & $(80,5-99,3)$ & $(5,0-338,1)$ & $(71,0-88,2)$ \\
\hline
\end{tabular}

Таблиця 6. Діагностична цінність морфологічних ознак спермограми чоловіків при роботі в умовах низьких температур

\begin{tabular}{lcccc}
\hline \multicolumn{1}{c}{ Показник } & $\begin{array}{c}\text { Чутливість } \\
(95 \% \text { ДI) }\end{array}$ & $\begin{array}{c}\text { Специфіч- } \\
\text { ність } \\
(95 \% \text { ДІ) }\end{array}$ & $\begin{array}{c}\text { ВШ } \\
(95 \% \text { ДI) }\end{array}$ & $\begin{array}{c}\text { Площа під } \\
\text { RоC- } \\
\text { кривою } \\
(95 \% \text { ДІ) }\end{array}$ \\
\hline Кількість нормальних за морфо- & 51,2 & 96,0 & 25,1 & 73,6 \\
логією сперматозоїдів & $(36,8-65,4)$ & $(80,5-99,3)$ & $(3,1-202,8)$ & $(65,2-82,0)$ \\
Наявність аномальних & 55,8 & 96,0 & 30,3 & 75,9 \\
сперматозоїдів & $(41,1-69,6)$ & $(80,5-99,3)$ & $(3,8-244,8)$ & $(67,6-84,3)$ \\
Наявність фрагментації ДНК & 39,5 & 96,0 & 15,7 & 67,8 \\
Наявність патології голівок & $(26,4-54,4)$ & $(80,5-99,3)$ & $(1,9-127,1)$ & $(59,5-76,0)$ \\
сперматозоїдів & 34,8 & 92,0 & 6,2 & 63,4 \\
Наявність патології акросоми & $(22,4-49,8)$ & $(75,0-97,7)$ & $(1,3-29,8)$ & $(54,6-72,3)$ \\
сперматозоїдів & 44,2 & 96,0 & 19,0 & 70,1 \\
Наявність патології джгутика & $(30,4-58,8)$ & $(80,5-99,3)$ & $(2,4-153,5)$ & $(61,7-78,4)$ \\
& 62,7 & 96,0 & 40,5 & 79,4 \\
& $(47,8-75,6)$ & $(80,5-99,3)$ & $(5,0-328,7)$ & $(71,2-87,6)$ \\
\hline
\end{tabular}

Прогностична цінність виявлення патології голівок сперматозоїдів в умовах високих температур була вірогідною за всіма показниками і становила: чутливість 68,4 (95\% ДІ 52,5-80,9), специфічність 92,0 (95\% ДІ 75,0-97,7), площа під ROC-кривою 80,2 (95\% ДІ 71,1-89,3). Водночас показники хибнонегативного тесту були невисокими (див. табл. 5).Також патологія голівок сперматозоїдів у чоловіків, які працюють в умовах низьких температур, була цінною якісною ознакою порушення спермограми з вірогідними показниками прогностичної цінності (див. табл. 6).

Дефект акросоми виявляли за ї̈ відсутністю, асиметрією, розміщенням, зменшенням розміру. Показники діагностичної цінності при роботі в умовах високих та низьких температур порівняно з контрольною групою були вірогідними та приблизно однаковими (див. табл. 5 та 6).

Патологію джгутика виявляли за відсутністю, вкороченням, «надломом», подвоєнням (див. табл. 5 та 6): чутливість 63,1 (95\% ДІ 47,3-76,6) та 62,7 (95\% ДІ 47,8-75,6), специфічність 96,0 (95\% ДІ 80,5-99,3) та 96,0 (95\% ДІ 80,5-99,3), ВШ 41,1 (95\% ДІ 5,0$338,1)$ та 40,5 (95\% ДІ 5,0-328,7), площа під ROC-кривою 79,6 (95\% ДІ 71,0-88,2) та 79,4 (95\% ДІ 71,2-87,6). Усі параметри прогностичної цінності були вірогідними, окрім вірогідності хибнопозитивного тесту $(4,0 ; 95 \%$ ДІ 0,71-19,5) в обох групах.

\section{Висновки}

Вивчення особливостей морфології сперматозоїдів та показників ендокринного статусу у чоловіків, які працюють в умовах високих та низьких температур, показало, що:

1. Гормональний статус чоловіків, які працюють в умовах високих температур, відрізняється високим вмістом ЛГ $(p=0,013)$.
У групі чоловіків, які працюють в умовах низьких температур, зміни гормонального статусу невірогідні.

2. Найнижчу кількість сперматозоїдів верифіковано у групі чоловіків, які працюють в умовах високих температур. Встановлено наявність вірогідного від'ємного кореляційного зв'язку між загальною кількістю сперматозоїдів в еякуляті та тривалістю професійного анамнезу в чоловіків, які працюють в умовах високих $(r=-0,67 ; p<0,05)$ та низьких $(r=-0,36 ; p<0,05)$ температур.

3. В умовах впливу високих та низьких температур кількість сперматозоїдів (як загальна, так і в 1 мл еякуляту) вірогідно менша $(p<0,05)$, ніж у групі контролю.

4. Кількість рухливих сперматозоїдів - найбільш «вразливий» параметр при впливі низьких температур $(p<0,05)$.

5. Для високих температур «вразливими» параметрами $€$ зменшення загальної кількості сперматозоїдів в 1 мл еякуляту $<15,0 \%(78,9 \%)$, кількості живих сперматозоїдів <58,0\% $(65,8 \%)$, кількості сперматозоїдів з поступальним рухом <32,0\% $(60,5 \%)$

6. Частота виявлення патозооспермії вища при впливі високих температур (чутливість 81,6 (95\% ДІ 66,5-90,8), специфічність 96,0 (95\% ДІ 80,5-99,3)). При дії низьких температур діагностична цінність виявлення патозооспермії нижча.

7. Діагностична цінність наявності фрагментації ДНК сперматозоїдів в умовах високих температур встановлена на рівні 78,9 (95\% ДІ 63,6-88,9) (чутливість) та 96,0 (95\% ДІ 80,5-99,3) (специфічність). Нижчою була діагностична чутливість та специфічність виявлення фрагментації ДНК сперматозоїдів в умовах низьких температур. Дефект акросоми при дії високих та низьких температур не був характерною ознакою.

\section{Список використаної літератури}

м03 України (2003) Наказ М03 України від 15.12.2003 р. № 582 «Про затвердження клінічних протоколів 3 акушерської та гінекологічної допомоги» (https://z-I.com.ua/ua/new582/)

Тимченко О.І., Микитенко Д.О., Коба О.П., Линчак О.В. (2014) Рівень безпліддя в областях за даними М03 України. Мед. перспект., 19(3): 105-111.

Arya S.T., Dibb B. (2016) The experience of infertility treatment: the male perspective. Hum. Fertil. (Camb.), 19(4): 242-248.

Meniru G.I. (2004) Cambridge guide to infertility management and assisted reproduction. Cambridge University Press, $276 \mathrm{p}$.

Ozelci R., Yılmaz S., Dilbaz B. et al. (2016) Seasonal variation of human sperm cells among 4,422 semen samples: A retrospective study in Turkey. Syst. Biol. Reprod. Med., 62(6): 379-386.

Punab M., Poolamets 0., Paju P. et al. (2017) Causes of male infertility: a 9 -year prospective monocentre study on 1737 patients with reduced total sperm counts. Hum. Reprod., 32(1): 18-31.

Rebrova O.Yu. (2004) Statistical analysis of medical data. Application of STATISTICA Software package. Media-Sphere, Moscow, 312 p.

Shcheplev P.A., Apolikhin O.I. (2010) Male infertility. Consensus discussion. Bull. Reprod. Health, 3-4: 37-44.

\section{Особенности эндокринного статуса и количественные нарушения}

\section{спермограммы у мужчин, работающих в условиях высоких и низких температур}

\section{E.А. Ломейко}

Резюме. Цель - изучить особенности морфологии сперматозоидов и показатели эндокринного статуса у мужчин, работающих в условиях высоких и низких температур. Объект и методы исследования. В период 2013-2017 гг. обследованы спермограммы пациентов $(n=81)$, которые на протяжении профессиональной деятельности находились под влиянием низких $(n=43)$ или высоких $(n=38)$ температур. Результаты. Гормональный статус мужчин, работающих в условиях высоких температур, характеризуется повышением содержания лютеинизирующего гормона ( $p=0,013)$. В группе мужчин, работающих в условиях низких температур, изменения гормонального статуса недостоверны. Доказано наличие отрицательной корреляционной связи между общим количеством сперматозоидов в эякуляте с продолжительностью профессионального анамнеза при работе в условиях высоких $(r=-0,67 ; p<0,05)$ и низких $(r=-0,36$; $p<0,05)$ температур. Выводы. В условиях воздействия высоких и низ- 
ких температур количество сперматозоидов (как общее, так и в 1 мл эякулята) достоверно меньше, чем в группе контроля ( $p<0,05)$. Количество подвижных сперматозоидов наиболее «уязвимо» при воздействии низких температур $(p<0,05)$. Для высоких температур «уязвимыми» параметрами являются уменьшение общего количества в 1 мл эякулята <15,0\% (78,9\%), количества живых сперматозоидов $<58,0 \%(65,8 \%)$, количества сперматозоидов с поступательным движением $<32,0 \%(60,5 \%)$.

Ключевые слова: эндокринный статус, сперматозоиды, морфологические изменения, низкие температуры, высокие темпера туры.

\section{Features of endocrine status and quantitative disorders of spermogram in men working in the conditions of high and low temperatures}

\subsection{Lomeiko}

Summary. Aim - to study the morphology of spermatozoids and endocrine status indicators in men who work in the conditions of high and low temperatures. Materials and methods. During 2013-2017, spermograms of 81 patients were examined, which during the professional activity were influenced by low $(n=43)$ or high $(n=38)$ temperatures. Results. It has been established that the hormonal status of men who work in the conditions of high temperatures is characterized by a likely increase in the content of luteinizing hormone $(p=0.013)$. In a group of men working in the conditions of low temperatures, changes in hormonal status are unlikely. A negative correlation between the total number of spermatozoids in ejaculate with the duration of a professional anamnesis during work in high ( $r=-0.67$; $p<0.05)$ and low $(r=-0.36 ; p<0.05)$ temperatures is proved. Conclusions. It was found that under the conditions of high and low temperatures, the number of spermatozoids, both general and per $1 \mathrm{ml}$ of ejaculate, was significantly lower $(p<0.05)$ than in the control group. The indicator of the number of active spermatozoids $(p<0.05)$ was the most «vulnerable» under the influence of low temperatures. It has been established that for high temperatures «vulnerable» parameters included the reduction in the total number per $1 \mathrm{ml}$ of ejaculate of $<15.0 \%$ (78.9\%), in the number of live spermatozoids of $<58.0 \%(65.8 \%)$, in the number of spermatozoids with translational motion of $<32.0 \%(60.5 \%)$.

Key words: endocrine status, spermatozoids, morphological changes, low temperatures, high temperatures.

\section{Адреса для листування:}

Ломейко Олена Олександрівна

69035, Запоріжжя, просп. Маяковського, 26

Запорізький державний медичний університет,

кафедра акушерства, гінекології

та репродуктивної медицини ФПО

E-mail: elena.bogomaz1009@gmail.com

\section{РЕФЕРАТИВНА ІНФОРМАЦІЯ}

\section{Острая перфорация язвы желудка:}

лапароскопическая хирургия - альтернатива

\section{открытой хирургической операции}

Острая перфорация пептических язв желудка сопровождается высоким риском летальности. Частота развития данного осложнения практически неизменна и составляет 1,5-3\%, оставаясь второй по частоте причиной обращения за неотложной помощью пациентов с абдоминальной патологией и показанием к неотложной хирургической операции. Малоинвазивные технологии все шире внедряются в традиционную хирургическую практику. Предложенный метод лапароскопического устранения перфорации пептической язвы желудка при ее осложненном течении получил широкое распространение в последнее время, хотя имеет определенные ограничения.

Всесторонняя оценка метода лапароскопического устранения перфорации желудка на фоне осложненного течения язвенной болезни предпринята коллективом авторов во главе с Антонио Мирабелла (Antonino Mirabella) из Университетской клиники города Палермо, Италия. В работе проведен ретроспективный сравнительный анализ результатов лечения при пептической перфорации желудка: лапароскопическим и традиционным хирургическим методом. Основанием для того или иного метода терапии была шкала оценки риска развития осложнений, предложенная Boey.

В ретроспективный анализ включены результаты невыборочного последовательного хирургического лечения при перфорации желудка на фоне осложненного течения язвенной болезни у 184 пациентов. Идентификация пациентов проведена в соответствии с Международной классификацией болезней: ICD-9: 531.1, 531.5, 532.1 , 532.5, 533.1, 533.5; а также с учетом демографических данных, включая возраст, пол и степень физического состояния по шкале ASA (Классификация Американского общества анестезиологов) а также риск развития осложнений по шкале Воеу. Статистическая обработка данных выполнена с использованием программного обеспечения SPSS (Чикаго, штат Иллинойс, США).

Среди оперированных - 61 женщина и 123 мужчины. Средний

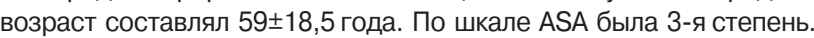
Состояние шока при госпитализации отмечали у 64 (34,7\%) участников исследования. Длительность заболевания составила более 1 сут с момента развития клинической картины у 565 (30,4\%) пациентов. 128 пациентов отнесены книзкому и умеренному классурискапо Воеу (0-2); 56 - к высокому (3) классу риска. Вид оперативного вмеша- тельства в зависимости от степени риска представлен в табл. 1, а разновидность оперативного вмешательства - в табл. 2.

Таблица 1. Вид операции и количество пациентов в зависимости от степени риска по Воеу

\begin{tabular}{|c|c|c|}
\hline Степень риска & Открытая операция & Лапароскопия \\
\hline $0-2$ & 53 & 75 \\
\hline 3 & 56 & 0 \\
\hline
\end{tabular}

Таблица 2. Разновидность хирургической техники закрытия перфорационного отверстия

\begin{tabular}{|l|c|c|}
\hline Хирургическая техника & Открытая операция & Лапароскопия \\
\hline Ушивание перфорации & 86 & 64 \\
\hline Ушивание + оментопексия & 20 & 9 \\
\hline Только оментопексия & 3 & 2 \\
\hline Всего & $\mathbf{1 0 6}$ & $\mathbf{7 5}$ \\
\hline Летальность, \% & 21,4 & 4,7 \\
\hline
\end{tabular}

В результате проведенного исследования авторы пришли к заключению, что на процесс принятия решения о выполнении лапароскопической или традиционной операции при перфорации пептической язвы решающее значение имеет шкала риска Воеу: пациентам высокого риска показано оперативное лечение $(p=0,000)$. Развитие постоперационных осложнений также коррелировало с оценочной шкалой: в группе умеренного и среднего риска они составили 4,7\% (лапароскопия); в группе высокого риска (оперированные традиционно) - 21,4\%. При этом частота поздних осложнений не зависела от вида вмешательства: $12,8 \%(p=0,092)-$ традиционная операция и 5,3\% ( $p>0,05)$ - лапароскопия, но имело место статистически достоверное различие заболеваемости и смертности между пациентами в возрасте $<70$ и $>70$ лет ( $p=0,000$ и p=0,002).

Лапароскопическую методику устранения язвенной перфорации можно рассматривать на сегодня как альтернативу хирургическому методу лечения при осложненном течении язвенной болезни желудка. При этом риск развития осложнений и летальных исходов коррелирует с оценкой по шкале Воеу, риск тем выше, чем выше балл по шкале. Выбор лапароскопического метода устранения перфорации пептической язвы в соответствии со шкалой предполагается у пациентов с низким и умеренным риском осложнений по шкале $(0-\leqslant 2)$ и не используется в ситуации умеренно высокого и высокого риска.

Mirabella A., Fiorentini T., Tutino R. et al. (2018) Laparoscopy is an available alternative to open surgery in the treatment of perforated peptic ulcers: a retrospective multicenter study. BMC Surg., 18(1): 78 (doi: 10.1186/s12893-0180413-4).

Александр Осадчий 